\title{
ВИРТУЕЛНА КУЛТУРА У ПРОЦЕСИМА РАЗВОЈА, ПРЕЗЕНТАЦИЈЕ И ОЧУВАҢА КУЛТУРЕ САВРЕМЕНОГ ДРУШТВА
}

\section{Сажетак}

Развој друштва и савремене технологије довели су до формирања нових појавних видова друштва као што су информационо и дигитално друштво и појаве виртуелних организација и виртуелних заједница. Рад ће представити значај информационо-комуникационих технологија у савременом друштву, дигитално окружење и дигитализационе процесе најпре кроз планове, стратегије и дигиталне агенде (у Европи и код нас), потом представити стање у друштву и најзначајније резултате њихове примене. Виртуелна култура биће размотрена кроз нове појавне облике који омогућавају представљање културе и достигнућа савременог друштва: QR кодови, увећана стварност (AR), виртуелна стварност (VR), развој Интернета и концепт Интернет ствари (IoT), потом формирање виртуелних библиотека, уз „облак" технологију и примере LoCloud платформе за организовање и презентацију дигитализованог садржаја у библиотекама и другим баштинским институцијама, унапређење дигиталне писмености у друштву и очување културе.

Кључне речи: виртуелна култура, информационо-комуникациона технологија, дигитализација, дигитална писменост

Развој друштва и савремене технологије утицали су на целокупну друштвену сферу и културу и довели до формирања нових информационо оријентисаних појавних видова друштва као што су информационо друштво и дигитално друштво. Свеприсутност дигитализационих процеса и дигитално окружење утицали су на формирање виртуелних организација и виртуелних заједница. Виртуелна култура постала је саставни део савременог друштва уз значајну улогу информационо-комуникационих технологија у свакодневном животу. Дигитално окружење може се узети као прихваћена основа данашњице у својим различитим појавним видовима, почев од дигиталног издаваштва, дигиталних 
књига и публикација, до дигиталних библиотека, мрежа, апликација на мобилним уређајима, технологије Информационог облака и Интернета ствари. Значај дигиталног развоја и дигиталног окружења огледа се како у образовној сфери, тако и у научном напретку и стручном развоју најширег спектра дисциплина, економском степену и степену развоја друштва, па све до задовољавања лудичких потреба поједнаца и креативног испуњавања слободног времена. Текстуални, графички, аудио и видео садржај на традиционално аналогним медијима добијају своју напредну електронску, дигиталну верзију уз могућност обједињеног представљања у новој форми мултимедијалног садржаја. Тако имамо електронске верзије традиционалних медија: ЦД и ДВД-ром, е-књигу, електронски часопис, онлајн магазин и новине, ПДФ... али и потпуно нове медије као што су: блог, колаборативни софтвер или групвер ${ }^{1}$, апликације за израду дигиталне публикације, апликације за мобилне електронске уређаје, подкаст и др.

Савремено доба у коме живимо окарактерисано је процесима развоја и достигнућима науке, технике и технологије. Утицај овог напретка на развој друштва огледа се у многим сферама међу којима се посебно издваја дигитализација, при чему се, разматрајући друштвене процесе и појаве, може закључити, да је у току доба, прецизније, ера дигитализације. Овај закључак има утемељење у 1) броју раличитих појавних облика дигиталних уређаја, 2) укупном броју дигиталних уређаја и 3) броју дигиталних апликација и система са широким дијапазоном примена у друштву.

Дигиталне информације и извори свеприсутни су у нашем друштву: управљају привредом, економијом, поспешују процесе образовања, унапређују науку и развој технологије, представљају и подстичу културу, омогућују дигиталну управу, повезују појединце и целу заједницу трансформишући га у дигитално друштво.

Примене дигитализације у друштву присутне су у многим областима: Наука у овиру бројних научних дисциплина базира своја истраживања на дигиталној технологији и уређајима. У медицини, сва-

1 Софтвер који омогућава сарадњу већег броја лица, тзв. групвер, омогућава повезаност и продуктивност већег броја појединаца и тимова. Пример је Гугл докс (Google Docs) који омогућава ефикасно обављање одређених радних задатака унутар тимова или организације. 
кодневно се користе рендген апарати, ултразвучни апарати, скенери, компјутерска томографија... Индустрија и привреда - роботика, контрола уређаја, управљање индустријским постројењима, смањење ризика, контрола процеса, машина и електромотора, производња аутомата, енергетика, авио-индустрија итд. зависе од дигиталне технике, преноса и обраде података. Образовање: електронске табле, уређаји за креирање и приказивање наставног садржаја, Мудл (MOODLE) и MOOC рачунарска платформа за удаљено и електронско учење, дигитални и електронски семинари - вебинари умногоме су поспешили развој образовања и унапредили концепт перманентног усавршавања односно доживотног учења. Енергетика, нарочито коришћење соларне енергије и енергије ветра, уз прекидаче, трансформаторе и мерне уређаје омогућавају конвертовање, пренос, мерење енергије, ослоњени на дигиталну технику. Култура, покретна и непокретна културна добра и остварења културне баштине уследпротока времена, изложени утицајима агенаса и пропадљивости материјала подложни су оштећивању и угрожености од пропадања, али се археолошкиа налазишта, споменици, рукописи, штампани извори и други артефакти културе кроз процесе дигитализације могу сачувати за будуће генерације. Телекомуникације користећи мобилну телефонију, бежичне телефоне, факс уређаје за пренос гласа али и података, рачунаре и рачунарске мреже уз интернет, омогућиле су креирање, пренос, пријем, обраду и коришћење дигиталног садржаја на даљину у најразличитијој форми: текст, звук, видео, мултимедији као и огромне количине података. Обрада звука кроз креирање дигиталног или снимање аналогног звучног садржаја, конверзија аналогног у дигитални - дигитализација аналогног сигнала, филтрирање, уклањање шумова, снимање на медије, форматирање и чување све до репродукције ослања се на рачунаре и друге уређаје у дигиталној обради звука. Обрада говора обавља се различитим апликацијама које омогућавају препознавање говора, синтетизацију, превод текста у говор, дигитално превођење, пренос говора и др. остварују се путем телефона и других дигиталних уређаја високим квалитетом. Обрада слика, рестаурација, графике, фото и слајд материјала, радари и сонари, сеизмолшка обрада података, временска прогноза усмерени су на дигиталне изворе и обраду података. Обрада видео материјала 
у највећој мери обавља се на моћним рачунарима уз употребу дигиталних камера, дигиталних фототапарата, камкордера. Телевизија је унапређена кроз дигитализацију сигнала преласком са аналогног на дигитално емитовање уз побољшање квалитета слике и звука уз мноштво функција на дигиталним телевизорима и сличним паметним уређајима (уз ЛЕД и ЛЦД мониторе). Обрада текста, штампарство и издаваштво усмерени су не само на традиционална, класична издања на папиру, већ и на електронску форму, од часописа, преко дигиталних књига па све до апликација и платформи за читање на електронским читачима и мобилним телефонима. Електронски уређаји у домаћинству: бежични и мобилни телефони, телевизори, модеми, рачунари, лаптопови, таблети, различити плејери, ласерски штампачи... само су неки од уређаја дигиталне ере који нам олакшавају свакодневни живот. Пример је савремени концепт Интернет ствари (loT - Internet of Things) који обухвата управљање физичким објектима, уређајима у домаћинству, возилима, објектима опремљеним сензорима, електроником и софтвером, повезаним на интернет мрежу која омогућава прикупљање и размену података, односно укључивање уређаја, контролу, предвиђање и интеракцију на основу праћења параметара. Е-управа омогућава грађанима једноставније приступање административним и правним услугама а друштву транспарентније, ефикасније и економски исплативије пословање и управљање.

Развој „дигиталног доба“ огледа се у 1) значају информација и 2) у измењеном схватању улоге коју информација има у друштву (услед пораста количине информација, броја и разноврсности носилаца информација, економског раста информационог сектора у модерним економијама, брзине технолошких промена и утицаја технологије на друштво).

\section{Мерење дигитализације}

Примена савремених информационих технологија кључни је фактор развоја друштва. Значај информационо-комуникационих технологија (ИКТ) данас толики је да се утицај развоја и стање ИКТ распростире на друштво у целини, те у значајној мери одређује стање, дефинише токове 
и трансформише економске и друштвене активности, простирући се до економске продуктивности и прихода друштва. Значај парне машине и железнице у 19. веку, електрификације у 20. веку, сада у 21. веку има телекомуникациона инфраструктура. Информационе технологије значајно су средство које омогућава и поспешује капацитете за развој друштва. Начин, интензитет и употреба информационих технологија дефинише на ком је нивоу развоја једна заједница, уз будуће иновације базиране на знању са циљем унапређења друштва: подизање животног стандарда, модернизацију друштва и прогрес. Да је примена савремених информационих технологија кључни фактор развоја друштва говори и потреба квантификације утицаја информационих и комуникационих технологија на друшштво и чињеница да се степен напретка друштва може мерити Индексом ИКТ развијености ${ }^{2}$ - развијеним од стране Међународне телекомуникационе уније ${ }^{3}$ и Индексом дигитализације прихваћеним за меру нивоа дигитализованости земаља5 5

Индекс ИКТ развијености развила је Међународна телекомуникациона унија6 ${ }^{6}$ специјализована агенција Уједињених нација за информационе и комуникационе технологије у Женеви, са циљем праћења напретка развоја и примене информационих и комуникационих технологија како у земљама у развоју тако и у економски развијеним земљама. Друга могућа примена је сагледавање и мерење глобалног дигиталног јаза и развојног потенцијала које земље имају коришћењем информационих и комуникационих технологија. Овај индекс значајан је алат за вредновање и бенчмаркинг најважнијих показатеља за мерење информационог друштва - стандардни је алат који владе, оператери, развојне агенције, истраживачи и институције могу користити за мерење дигиталног јаза и упоређивање ИкТ перформанси унутар једне, али и унакрсно између земаља, јер и поред чињенице да информационо-комуникационе технологије све више постају доступне и стандард у друштву и даље постоји итражен информациони и дигитални јаз међу земљама у развоју и економско-

2 IDI (The ICT Development Index) - Индекс развоја ИКТ

3 ITU - International Telecommunication Union

4 Digitization Index

5 концепт развијен од стране Booz \& Company консултантске куће

6 ITU - International Telecommunication Union 
технолошки развијених земаља.

Индекс развоја ИКТ је композитни индекс сачињен од 11 индикатора укомбинованих у једну референтну меру која служи у сврхе праћења и поређења развоја информационо-комуникационих технологија. Индекс ИКТ темељи се на систему од 11 показатеља сврстаних у три подсистема7:

1. Подсистем приступа (обухвата пет индикатора који се односе на инфраструктуру и приступ),

2. Подсистем коришћења (сачињен од три индикатора који се односе на интензитет употребе ИКТ), и

3. Подсистем вештина (чине га три индидкатора који се односе на базичне показатеље о нивоу способности и вештина за овладавање ИКТ).

Развијен од стране чланица Међународне уније за телекомуникације 2008. године индекс развоја ИКТ први пут је представвљен 2009. године у Извештају мерења информационог друштва ${ }^{8}$ за више од 160 економија у свету, у издању ITU, и од тада се редовно годишње објављује. ${ }^{9}$ Извештај мерења информационог друштва од 2015. године приказује ниво ИКТ развоја у 167 привреда у свету, упоређује напредак и истиче оне земље које су најбрже, најдинамичније и највише, или укупно, побољшали своју позицију на ранг листи од 2010. године, уз приказ и анализу коришћења фиксне и мобилне телефонске мреже и широкопојасне интернет мреже, као и најновије догађаје у сфери Интернет ствари $\left(\right.$ Иот $\left.^{10}\right){ }^{11}$ Према последњем извештају мерења стања и напретка информационог

7 Katz, Raúl L. and Koutroumpis, Pantelis, „Measuring digitization: A growth and welfare multiplier", Technovation, Volume 33, Issues 10-11, October-November 2013, pp 314319, (2013), http://www.teleadvs.com/wp-content/uploads/Technovation_RK_PK.pdf (преузето 17.3.2017), DOI:10.1016/j.technovation.2013.06.004; (MEASURING the Information Society Report 2014, Geneva, International Telecommunication Union, стр. 35-37, URL (1.3.2017): https://www.itu.int/en/ITU-D/Statistics/Documents/publications/ mis2014/MIS2014_without_Annex_4.pdf

8 Measuring the Information Society Report

9 MISR извештај: MEASURING the Information Society Report 2014, Geneva, International Telecommunication Union, cтp. 35, URL (17.3.2017): https://www.itu.int/en/ITU-D/Statistics/Documents/publications/mis2014/MIS2014_without_Annex_4.pdf

10 loT - Internet of Things

11 URL (1.3.2017): https://www.itu.int/pub/D-IND-ICTOI 
друштва из 2015. године ${ }^{12}$ првих пет земаља које имају највиши ниво или су највише напредовале су: 1. Република Јужна Кореја, 2. Данска, 3. Исланд, 4. Уједињено краљевство, 5. Шведска. Кинески Хонг Конг, Норвешка и Јапан заузимају од деветог до једанаестог места, док Србија заузима педесетпрво место (испод Словеније (33) и Хрватске (42), а изнад Македоније (60), Црне Горе (65) и Босне и Херцеговине која заузима 77. место).

Мерење развијености информационо-комуникационих технологија поједине земље и утицај на друштво може се одредити и посредно представити и Индексом дигитализације. Као прихваћена мера нивоа дигитализованости земаља индекс се одређује од 2004. године за 150 држава. Земље су подељене према нивоу дигитализованости у четири групације, при чему вредност индекса дигитализације може бити у распону 0-100 на скали, при чему је вредност 100 максимална вредност индекса дигитализације:

1. Неразвијене економије (индекс дигитализације <25): Авганистан, Алжир, Ангола, Аруба, Бангладеш, Белизе, Боливија, ..., Вијетнам, Замбија,

2. Економије у развоју, са индексом дигитализације између 25 и 30: Албанија, Антигва и Барбуда, Јерменија, Азербејџан, Босна и Херцеговина, Боцвана, Бразил, Кина, Костарика, Еквадор, ..., Македонија, Тринидад и Тобаго, Венецуела,

3. Економије у транзицији са индексом дигитализације између 30 и 40 као што су Аргентина, Бахреин, Барбадос, Бугарска, Чиле, Колумбија, Хрватска, Кипар, Естонија, Иран, Јордан, Кувајт, Летонија, Макао, Малезија, Малта, Маурицијус, Мексико, Црна Гора, Оман, Филипини, Катар, Саудијска Арабија, Србија, Сејшели, Турска, Украјина, Уругвај,

4. Развијене економије (индекс дигитализације >40): Аустралија, Аустрија, Белорусија, Белгија, Чешка, Данска, Финска, Француска, Немачка, Грчка, Хонгконг, Мађарска, Исланд, Ирска, Израел, Италија, Јапан, Јужна Кореја, Канада, Литванија, Луксембург, Холандија, Нови Зеланд, Норвешка, Пољска, Португалија, Румунија, Русија, САД, Син-

12 Measuring the Information Society Report 2015, International Telecommunication Union, Place des Nations, Geneva, Switzerland, URL (12.3.2017): https://www.itu.int/dms_pub/ itu-d/opb/ind/D-IND-ICTOI-2015-SUM-PDF-E.pdf 
гапур, Словачка, Словенија, Шпанија, Шведска, Швајцарска, Тајван, Уједињени Арапски Емирати, Велика Британија.

Индекс дигитализованости развила је компанија „Strategy \&“ (некадашња „Booz \& Company“) и сачињен је као композитни индекс који се састоји од 23 индикатора ${ }^{13}$ :

Табела 1: Листа индикатора и извора Индекса дигитализације

\begin{tabular}{|c|c|}
\hline ИНДИКАТОР & ИЗВОР \\
\hline Тарифа за фиксне телефонске линије & ITU \\
\hline Тарифа за прикључење фиксне телефонске линије & ITU \\
\hline Тарифа за мобилни припејд & ITU \\
\hline Тарифа за мобилни припејд прикључак & ITU \\
\hline Тарифа за фиксни широкопојасни приступ Интернету & ITU \\
\hline $\begin{array}{l}\text { Инвестиције по телеком претплатнику (мобилни, } \\
\text { широкопојасни и фиксни прикључак) }\end{array}$ & Светска банка \\
\hline Пенетрација фиксних широкопојасних прикључака & ITU \\
\hline Пенетрација мобилне телефоније & ITU \\
\hline Становништво покривено мрежом мобилне телефоније & ITU \\
\hline Проценат популације која користи ПЦ рачунар & ITU \\
\hline 3G Пенетрација & WirelessIntelligence \\
\hline $\begin{array}{l}\text { Међународни интернет проток (битова у секунди / } \\
\text { интернет корисник) }\end{array}$ & ITU \\
\hline Широкопојасне брзине (\% изнад 2 Mbps) & Akamai \\
\hline $\begin{array}{l}\text { Интернет малопродаја (проценат Интернет малопродаје } \\
\text { од укупне малопропродаје) }\end{array}$ & Euromonitor \\
\hline Е-управа, индекс спремности за е-управу & УН \\
\hline Проценат појединачних корисника Интернета & ITU \\
\hline Просечан приход по кориснику бежичних мрежа & WirelessIntelligence \\
\hline $\begin{array}{l}\text { Број јединствених посета друштвених мрежа на Интернету } \\
\text { по становнику }\end{array}$ & Internet World Stats \\
\hline Употреба SMS-а (просечан број SMS-ова по кориснику) & WirelessIntelligence \\
\hline Инжењери (проценат од укупног становништва) & Светска банка \\
\hline $\begin{array}{l}\text { Квалификованост радне снаге (процентуални удео радне } \\
\text { снаге са вишим образовањем од средњошколског, од } \\
\text { укупне радне снаге) }\end{array}$ & Светска банка \\
\hline
\end{tabular}

13 Извор: Katz, Raúl L., Using a Digitization Index to measure the Economic and Social Impact of Digital Agendas, стр. 7, http://www.eurocpr.org/data/2013/Katz.pdf (преузето 1.3.2017) 


\section{ИКТ и иницијативе, стратегије и планови у европским оквирима}

Улога и значај информационо-комуникационих технологија у развоју друштва, стању економије, привреде, културе, образовања, процесима државне управе и другим друштвеним сферама препознат је и кроз иницијативе у дигиталној сфери и доношење докумената и усвајања стратегија развоја информационог друштва у Европској унији.

У оквиру Европске уније ИКТ су препознате као битан чинилац утицаја на економски раст и иновативност, а међу седам водећих иницијатива економске стратегије Европа 2020 налази се Дигитална агенда за Европу, чиме се указује на значај који информационо-комуникационе технологије имају у развоју савремене економије. Европска комисија усагласила је свој дугорочни план за развој информационо-комуникационих технологија у периоду од 2010. до 2020. године којим се предвиђа:

1. да сва домаћинства у Европској унији до 2020. године добију могућност приступа Интернету брзином $30 \mathrm{Mb} / \mathrm{s}$,

2. да најмање половина становника Европе може да користи брзину $100 \mathrm{Mb} / \mathrm{s}$,

3. финансирање изградње заједничке оптичке мреже и подстицање држава чланица, приватног сектора и јавних предузећа да изграде сопствене мреже које би се на њу надовезале.

Посебан акценат ставља се на развој широкопојасног приступа у руралним срединама. Велике брзине широкопојасног приступа омогућавају грађанима и предузећима да комуницирају и производе на бржи и ефикаснији начин. Према истраживању ОЕЦД-а ${ }^{14}$ пораст улагања у област електронских комуникација за $8 \%$ условљава раст бруто друштвеног производа од 1\%, а на основу истраживања Светске банке повећањем пенетрације широкопојасних прикључака за $10 \%$ обезбеђује се раст бруто друштвеног производа од 1,38\% у земљама у развоју, односно 1,21\% у развијеном земљама. ИКТ сектор је директно заслужан за 5\% бруто националног прихода (БНП) у Европи, са тржишном вредношћу од 660 милијарди евра годишње, али

14 Rade Stankić, Marko Stankić, „Merenje ekonomskog i društvenog uticaja informacionokomunikacionih tehnologija“, Нови економист, бр. 14, стр. 70 
далеко више доприноси расту продуктивности (20\% директно из сектора ИКТ и 30\% из инвестиција у ИКТ). Висок степен динамичности и иновативности овог сектора и улога коју сектор има у промени начина пословања у другим секторима основни су разлози оваквом стању.

\section{Стратегија европе 2020}

Европска унија је 2010. године усвојила Стратегију за паметан, одржив и инклузивни развој под именом Cтратегија Европе $2020^{15}$ у којој дефинише визију до 2020. године. Визија садржи достизање високог нивоа упослености становништва, економију са ниском емисијом угљендиоксида, продуктивност и социјалну кохезију и треба да буде имплементирана кроз конкретне акције на нивоу ЕУ али и понаособ на националним нивоима. Европска комисија предлаже седам кључних иницијатива које ће подстаћи напредак у оквиру сваке приоритетне области ${ }^{16}$ :

1. Унија иновација

2. Млади у покрету

3. Дигитална агенда за Европу 17

4. Европа која есрикасно користи ресурсе

5. Индустријска политика за еру глобализације

6. Агенда за нове вештине и нова радна места

7. Европска платформа за борбу против сиромаштва.

Информационо-комуникационе технологије су идентификоване као кључне у остваривању циљева до 2020. године у Дигиталној агенди Европе ${ }^{18}$. Паметан раст обухвата јачање знања и иновација у ЕУ као покретача будућег раста што захтева повећање квалитета

15 Europe 2020 strategy, European Commision, Brussels, 2010, http://ec.europa.eu/ europe2020/index_en.htm (преузето 12.3.2017)

16 Srategija Evrope 2020, Kurs o digitalnoj agendi, http://www.e-jednakost.org.rs/kursda/ (преузето 12.3.2017); „ЕВРОПА 2020“: Cтратегија паметног, одрживог и инклузивног раста, Европска комисија, Брисел, 2010

17 са циљем бржег ширења широкопојасног Интернета како би се омогућило да домаћинства и фирме користе предности дигиталног јединственог тржишта

18 Heuse, P. and Zimmer, H., „The Europe 2020 strategy”, Economic Review, 2011, September (2011) 
образовања, јачање истраживачких капацитета, промовисање трансфера иновација и знања широм Уније, уз коришћење информационих и комуникационих технологија на најбољи начин и осигуравање да се иновативне идеје могу претворити у нове производе и услуге који стварају раст, квалитетна радна места и помажу у суочавању са европским и глобалним социјалним изазовима. Да би се постигао паметан, одржив и инклузивни раст Европа планира предузимања акција на плану 1) иновација, 2) образовања, обуке и целоживотног учења ${ }^{19}$ и 3) формирања дигиталног друштва услед глобалне потражње за информационим и комуникационим технологијама. Реализација овог плана представља тржиште вредно две хиљаде милијарди евра, али само четвртину покривају европске компаније. Европа такође заостаје и са увођењем широкопојасног интернета, што утиче на њену способност да уводи иновације, на ширење знања и дистрибуцију роба и услуга интернетом.

\section{Иницијатива Дигитална агенда за Европу}

У документу Европске уније Cтратегија Европа 2020 иницијатива под називом Дигитална агенда за Европу сагледавајући економску ситуацију у Европи, указује да је ИКТ сектор директно одговоран за 5\% европског бруто националног прихода, са вредношћу тржишта од 660 милијарди € годишње. ${ }^{20}$ Индиректни ефекти ИКТ посебно се одражавају на укупни раст продуктивности и то 20\% директно из ИКТ сектора и $30 \%$ од инвестиција у ИКТ. Значајан социјални утицај ИКТ огледа се у чињеници да је више од 250 милиона корис-

19 Према подацима Cmpamezије Европа 2020 четвртина укупног броја ученика има ниску читалачку писменост док свака седма млада особа прерано напушта школовање и обуку. Око 50\% младих стиче средњи ниво квалификација, што често не одговара потребама тржишта рада. Приближно свака трећа особа старости 25-34 године има високошколску диплому, што је ниже у поређењу са 40\% у САД и преко 50\% у Јапану. Према Шангајском индексу, само два европска универзитета су међу првих двадесет на свету (извор: Communication from the Commission, Europe 2020, A strategy for smart, sustainable and inclusive growth, Brussels, (2010), стр. 12, http://eur-lex.europa.eu/ LexUriServ/LexUriServ.do?uri=COM:2010:2020:FIN:EN:PDF (преузето 1.3.2017))

Europe 2020, http://ec.europa.eu/europe2020/index_en.htm (преузето 1.3.2017) 
ника дневно на Интернету. Будућа економија према наводима Дигиталне агенде за Европу биће мрежно базирана економија знања са Интернетом у свом центру. За остварење ових циљева Европи је потребан широко-распрострањен и ценовно приступачан брз (30 $\mathrm{Mb} / \mathrm{s}$ ) и ултрабрз (преко $100 \mathrm{Mb} / \mathrm{s}$ ) Интернет приступ.

У Cтратегији Европа 2020 посебно је истакнута важност примене широкопојасног приступа за промоцију социјалног укључивања и конкурентности у Европској унији што значи да развој брзих мрежа има револуционарни утицај и представља један од основних циљева ЕУ дефинисаних документом Дигитална Агенда за Европу. ${ }^{21}$

Планиране акције које ће предузети Европска комисија, на нивоу ЕУ како би циљеви Стратегије Европа 2020 били остварени су:

- обезбеђивање законских оквира који би стимулисали улагање у отворену и конкурентну инфраструктуру широкопојасног интернета и у повезане услуге;

- развијање ефикасне политике телекомуникација;

- поједностављење коришћења структурних фондова ЕУ;

- стварање јединственог тржишта за садржај и услуге помоћу интернета, што обухвата:

о отворене и безбедне интернет услуге

o $\quad$ заједничко тржиште дигиталних садржаја ЕУ

- стабилан регулаторни оквир са јасним режимом права,

- издавање лиценци које важе на више територија,

о одговарајућу заштиту и надокнаду за носиоце права и

- активну подршку дигитализацији европског богатог културног наслеђа, као и

о да обликује глобално управљање интернетом;

- реформисање фондова за истраживање и иновације

- повећање подршке у области информационих и комуникационих технологија ради повећања технолошке снаге Евро-

21 Циљ ове иницијативе је остварење одрживе економске и социјалне користи од дигиталног јединственог тржишта заснованог на широкопојасном интернету и интероперабилним апликацијама. Према плану то ће бити остварено увођењем широкопојасног приступа Интернету за све грађане Европе до 2013. године, а приступом Интернет везама много веће брзине (30 Mb/s и више) за све грађане ЕУ до 2020. године, док би најмање $50 \%$ европских домаћинстава требало да буде претплаћено на интернет везе изнад $100 \mathrm{Mb} / \mathrm{s}$. 
пе у кључним стратешким областима и стварања услова за раст малих и средњих предузећа како би она предводила тржишта у развоју;

- стимулисање иновација у информационим и комуникационим технологијама у свим секторима привреде;

- повећавање приступа интернету и омогућавање употребе свим европским грађанима, посебно кроз активности које подржавају дигиталну писменост и доступност.

- На националном нивоу, према Стратегији Европа 2020, државе чланице ЕУ биће обавезане да:

- израде функционалне стратегије широкопојасног интернета и усмере јавно финансирање, укључујући и структурне фондове, на области које нису потпуно покривене приватним улагањима;

- успоставе правни оквир за координацију јавних радова како би смањиле трошкове за развој мреже;

- промовишу размештање и коришћење модерних и доступних услуга помоћу интернета (е-управа, е-влада, онлајнздравље, паметан дом, дигиталне вештине, сигурност..). ${ }^{22}$

Иновативни сервиси као што су Интернет ствари, телемедицина, интелигентни транспорт, интерактивно учење и клауд технологија захтевају велике капацитете мрежне инфраструктуре па је фокус Дигиталне агенде Европе до 2020. године развој у области широкопојасности, коришћење Интернета, смањивање дигиталног јаза, е-трговина и ширење употребе онлајн јавних сервиса.

\section{Националне и регионалне дигиталне иницијативе, стратегије и планови у Европи}

Дигитални национални планови и стратегије разликују се од земље до земље. Према зацртаним плановима европске Стратегије 2020 државе чланице ће на националном нивоу морати да израде

22 Europe 2020 strategy, European Commision, Brussels, 2010, http://ec.europa.eu/ europe2020/index_en.htm (преузето 1.3.2017) 
функционалне стратегије за увођење широкопојасног интернета, поспеше јавно-приватно партнерство и усмере јавно финансирање, укључујући и структурне фондове, на области које нису потпуно покривене приватним улагањима; потом да успоставе правни оквир за координацију јавних радова како би смањиле трошкове за развој мреже; и да промовишу размештање и коришћење модерних и доступних услуга помоћу интернета (е-влада, онлајн-здравље, дигиталне вештине, паметне услуге).

Неке од иницијатива држава чланица ЕУ са добром праксом су: Француски дигитални план из 2010, Широкопојасна стратегија у Немачкој (Deutschland Digital 2015), Грчки ФТТХ програм јавноприватног партнерства, Програм Digital Britain из 2012. године на територији Велике Британије, План владе италијанске области Трентино као и закон Украјинског Министарства транспорта и комуникација о таксама на телекомуникације из 2010. године. ${ }^{23}$

Француским дигиталним планом из 2010. године предвиђене су инвестиције од 2 милијарде евра за развој врло брзог широкопојасног приступа у „сивим“ (делимично покривеним) и „белим“ (непокривеним областима) и израђена је студија развоја националне оптичке мреже којом се дефинише да се у наредних 15 година за 98\% француског становништва изгради оптичка инфраструктура.

Deutschland Digital 2015 - широкопојасна стратегија у Немачкој имала је за циљ да се до 2014. године за 75\% домаћинстава обезбеди приступ од $50 \mathrm{Mb} / \mathrm{s}$ или бржи кроз три стратешка принципа: тржишну конкуренцију тамо где је могућа; кооперацију у условима када само конкуренција није довољна да обезбеди развој широкопојасног приступа; и државну помоћ у изузетним случајевима где преостале варијанте нису успешне. ${ }^{24}$

Грчки ФТТХ програм ${ }^{25}$ јавно-приватног партнерства увођења фибер-оптичких каблова обухватао је амбициозни план грчке владе

23 Bogojević Dragan, Gospić Nataša, „Digitalna agenda: Evropa i Srbija”, (rad predstavljen na XXVIII Simpozijum o novim tehnologijama u poštanskom i telekomunikacionom saobraćaju - PosTel 2010, Beograd, Srbija, 14-15. decembar 2010.

24 IKT-Strategie der Bundesregierung „Deutschland Digital 2015“, Bundesministerium für Wirtschaft und Technologie, München: PRpetuum GmbH, 2010 
да обезбеди широкопојасни приступ преко оптичких мрежа у Атини, Солуну и 50 највећих грчких градова. За све друге општине и локалне заједнице предвиђено је да могу конкурисати за подстицајна средства ради градње властите инфраструктуре те је за изградњу оптичких мрежа до 2 милона домаћинстава планирана инвестиција од 2.1 милијарде евра, с тим што је економска ситуација у земљи успорила реализацију.

Национална стратегија Велике Британије Digital Britain, политички документ британске владе, објављена је 2009. године и као стратешка визија владе да земља буде водећа дигитална економија предвидела је да до 2012. године на територији Велике Британије буде доступан универзалан широпојасни приступ са протоком од 2 Mbps за шта је предвиђен посебан фонд од 200 милиона фунти како би се реформисале и унапредиле јавне службе. ${ }^{26}$

Италијанска област Трентино усвојила је регионалну стратегију да до 2018. године сваки становник регије добије широкопојасни приступ Интернету (broadband) од $100 \mathrm{Mbps}$, по пројекту који укључује успостављање јавно-приватне сарадње и формирање заједничке (joint venture) компаније, која ће инсталирати оптичке приступне мреже у урбаним и индустријским областима где су приватни оператори такође исказали интерес за инвестирање, уз процене да ће се на овај начин покрити 60-70\% потенцијалних корисника. Регионална влада ће затим радити на довођењу броудбенд приступа до удаљенијих области. Планирана средства за остварење овог плана, за регију у којој живи пола милиона становника, износе 300 милиона евра.

у Украјини је 2010. године Министарство транспорта и комуникација представило предлог закона по коме би се увођењем таксе од додатних 3\% на све телекомуникационе сервисе створио фонд који би се користио да компензује националном оператору проширење мреже у руралним и удаљеним областима у очекиваном износу од око 1.5 милиона евра годишње.

26 Digital Britain: Final Report, Department for Culture, Media and Sport and Department for Business, Innovation and Skills, (UK), 2009, https://www.gov.uk/government/uploads/system/uploads/attachment_data/ file/228844/7650.pdf (преузето 1.3.2016) 


\section{Национални планови, стратегије и агенде за дигитализацију у Републици Србији}

Значај дигитализације и електронске управе у развоју друштва код нас потврђује план Владе Републике Србије којим су дигитализација, образовање и економски развој приоритети владе уз оснивање Канцеларије за ИТ и електронску управу са задатком консолидације државних ИТ ресурса и повезивања различитих информационих система. План је да дигитализација државне управе и пружање услуга грађанима на једностван и брз начин буде основа развоја, унапређења квалитета, ефикасности, економичности и транспарентности јавне управе и допринесе даљем расту ИКТ сектора као једном од најбрже растућих сектора и омогућити даљи раст БДП-а и напредак привреде земље.

Дигитализацијом се отварају нове могућности за квалитетнији живот грађана кроз већи број услуга, јефтиније услуге, доступније информације и знање чиме се омогућују нова радна места, увећава извоз и пораст економије уз модернизацију друштва у свим сегментима. Процес дигитализације истиче се као најважнији катализатор развоја привреде и економије, услед конкуренције и раста извозног потенцијала ИТ индустрије од 10\% и софтвера од 20\% годишње.

Дигитализација културног наслеђа и савременог стваралаштва треба да буде законски дефинисана као културна активност, а примена информационо-комуникационих технологија као општи интерес у култури, тако да дигитализација постане обавеза установа које се баве заштитом, стваралаштвом и представљањем културног наслеђа.

Нацрт Cтратегије развоја културе Републике Србије 2017$2027^{27}$ у делу посвећеном дигитализацији културног наслеђа и сав-

Стратегија развоја културе Републике Србије од 2017. до 2027, нацрт, Министарство културе Републике Србије, мај 2017, URL: http://www.kultura.gov.rs/docs/dokumenti/ nacrt-strategije-razvoja-kulture-republike-srbije-od-2017--do-2027-/-nacrt-strategijerazvoja-kulture-republike-srbije-od-2017--do-2027-.pdf (прегледано 1.9.2017)

Предлог стратегије развоја културе Републике Србије од 2017. до 2027, Министарство културе Републике Србије, 2017, http://www.kultura.gov.rs/docs/ dokumenti/nacrt-strategije-razvoja-kulture-republike-srbije-od-2017--do-2027-/-nacrtstrategije-razvoja-kulture-republike-srbije-od-2017--do-2027-.pdf (прегледано 1.9.2017.) 
ременог стваралаштва уочава значај дигиталних технологија у процесу динамичног и отвореног приступа свим најважнијим садржајима који одређују културно памћење те област дигитализације културног наслеђа види као витално питање културне политике, па и опстанка културноисторијске заједнице.

Овом стратегијом предвиђа се да носиоци послова дигитализације буду установе културе на националном, покрајинском и локалном нивоу чији су оснивачи Република, покрајина или орган локалне самоуправе. Носиоци послова дигитализације могу бити и установе културе чији је оснивач физичко или правно лице, удружење грађана и самостални уметник, појединац или правно лице чије остварење спада у корпус дигиталне уметности или дигиталног наслеђа на основу Повеље Унеска о дигиталном наслеђу.

Под дигитализацијом националне културне баштине и савременог стваралаштва подразумева се свеобухватан поступак који укључује, али се не ограничава на:

- развој потпуних електронских каталога националне културне баштине, достигнућа савременог стваралаштва и учесника ове области;

- превођење из аналогне у дигиталну форму националне културне баштине и савременог стваралаштва и одговарајуће документације;

- описивање националне културне баштине и савременог стваралаштва;

- $\quad$ развој и повезивање програмске и физичке мреже информационих система о дигитализованој националној културној баштини и савременом стваралаштву;

- истраживање дигитализоване националне културне баштине и савременог стваралаштва;

- развој алата и инструмената, укључујући и правне, за различите врсте обраде и заштите дигитализоване националне културне баштине и савременог стваралаштва а посебно израду националног заштитног знака (watermark);

- дуготрајно чување дигитализоване националне културне баштине и савременог стваралаштва, укључујући и 
решавање проблема промене формата физичких носача и записа дигиталних информација, као и обезбеђивање чувања на више локација на поузданим носачима 28 ;

- мултимедијално представљање дигитализоване националне културне баштине и савременог стваралаштва;

- обезбеђивањетрајногипоузданогприступадигитализованој грађи, као и оптималног и безбедног коришћења те грађе за најразличитије намене без икаквих ограничења.

У процесу дигитализације културног наслеђа према треба спроводити стратешки принцип инсистирања на квалитету садржаја и приступа дигитализованом културном наслеђу. С друге стране треба дугорочно стварати општу друштвену свест о значају културног наслеђа и савременог стваралаштва уопште, као и о његовој дигитализованој презентацији и представљању, популарисању и ширењу. Према Стратегији принцип демократичности приступа се такође мора одржавати и на њему истрајавати како би доступност била омогућена свим заинтересованима, без обзира на узраст, физичка ограничења, познавање језика и техничку обученост уз бригу о приступачности дигитализоване грађе и интернет презентација установа културе, поштујући принципе универзалног дизајна и универзалног приступа као и Конвенцију УН о правима особа са инвалидитетом.

Од изузетног значаја је укључивање дигитализације културног наслеђа у курикулуме и наставне програме школа и универзитета.

Стратегија предвиђа да дигитализовано културно наслеђе и савремено стваралаштво треба да буде чувано и у архивској форми, у циљу заштите културног наслеђа, промоцији савременог стваралаштва и употпуњавања фондова институција које нису у могућности да буду у поседу оригиналних културних добара. Једном дигитализовано културно наслеђе и савремено стваралаштво треба да се користи за развој нових услуга и производа, организовано тако да се омогуће његово истраживање и примене у науци, образовању и, уопште, изградњи друштва заснованог на знању, као и у економском развоју земље.

28 сервери савремених и напредних перформанси, нестандардни цД и ДвД носачи намењени архивском чувању, екстерни хард дискови напредних перформанси и други носачи у складу са међународним стандардима потврђеним у пракси 
Дугорочно, дигитализовано и адекватно репрезентовано културно наслеђе и савремено стваралаштво треба да допринесе очувању националног идентитета и културне разноликости, те је од суштинског значаја развој вишејезичког окружења у коме ће дигитализовано културно наслеђе бити представљено.

Стандарди, њихово поштовање и доследна примена су у поступку дигитализације културног наслеђа веома значајни те је потребно ускладити и следити принципе и стандарде дефинисане на националном нивоу и усклађене са одговарајућим међународним смерницама које су формулисали Унеско, Савет Европе, Европска унија итд, чиме треба да буде постигнута интероперабилност, у земљи и у окружењу. ${ }^{29}$ Сарадња домаћих културних и научно-истраживачких институција на овом плану је неопходна а према Стратегији нарочито се односи на креирање одговарајућих упутстава и водича, проучавање, прилагођавање и примену стандарда за дигитализацију и обраду, изградњу система заштите дигитализованог садржаја и његово дуготрајно чување укључујући решавање проблема миграције приликом појаве нових технологија, стандарда и физичких носилаца дигиталних информација.

Према Cтратегији развоја културе Републике Србије од 2017. до 2027. поред савремене опреме и компетентних кадрова који ће бити у стању да реализују одговарајуће пројекте дигитализације културне баштине и успоставе сарадњу са другим учесницима у процесу, од посебног значаја је систематско омогућавање приступа брзом/ широкопојасном интернету за све установе културе те у складу са претпостављеним развојем информационог друштва, интернет треба да буде коришћен као главно средство представљања дигитализованог културног наслеђа.

Законском регулативом, односно подзаконским актима и правилницима потребно је дефинисати:

29 Посебно треба водити рачуна о усклађености са постојећим националним стратегијама у релевантним областима (Стратегија развоја информационог друштва до 2020, Стратегија развоја образовања до 2020, Стратегија научног и технолошког развоја 2016-2020, Стратегија развоја е-комуникација у Србији 2010-2020) и другим правним актима и препорукама (Листа стандарда интероперабилности - верзија 1.0 и др.) и стратегијама важним за развој ове области у региону и ширем окружењу, као што је Стратегија „Европа 2020“, Дигитална агенда ЕУ и Унескова повеља о очувању дигиталне баштине. 
- могућност приступа дигиталном садржају сходно правним дефиницајама ауторског права и заштите интелектуалне својине и права приватности,

- права на комерцијалну дистрибуцију јавно доступних дигитализованих садржаја,

- обавезност депозита дигиталних верзија нових издања, као и садржаја који су оригинално настали у дигиталној форми, и обавезне резервне копије на за то предвиђеном месту ван просторија установе, и

- права аутоматског прикупљања дигиталних садржаја (Webharvesting).

Анализа стања постојећег културног наслеђа, његове угрожености и доступности, претходи превођењу културног наслеђа и савременог стваралаштва у дигиталну форму, те је развој потпуних каталога први корак ка дигитализацији. Постојање дигиталних каталога, односно регистара дигитализоване грађе као јединствене базе података, израђен Национални портал треба да обезбеде систематски приступ дигитализацији, којим ће се избећи вишеструка дигитализација, различит квалитет или изостављање појединих делова услед потенцијалне некомплетности или оштећења појединих колекција у фондовима библиотека.

Стратегија развоја дигитализације културног наслеђа и савременог стваралаштва предвиђа и Акциони план чијим остваривањем циљева у периоду 2017-2027 у највећој мери би се довело до превазилажења тренутног раскорака у набавци и употреби савремене информационе и комуникационе технологије, оспособљености запослених у установама културе, разнородности техничких параметара различитих пројеката дигитализације и дефинисати стварне потребе за дигитализацијом културног наслеђа и савременог стваралаштва при чему би се избегло дуплирање, односно процес дигитализације учинио ефикаснијим и економски ефективнијим.

Акциони план за спровођење Cmpaтегије развоја културе Peпублике Србије од 2017. до 2027. године Министарства културе Републике Србије ${ }^{30}$ у делу Дигитализација културног наслеђа и савре-

30 Акциони план за спровођење Стратегије развоја културе Републике Србије од 2017. до 2027. године, Министарство културе Републике Србије, 2017, стр. 70, URL: http:// 
меног стваралаштва - Област културног развоја, за општи циљ има дигитализацију културног наслеђа и савременог стваралаштва ради квалитетнијег очувања садржаја и омогућавања његове доступности имајући за индикаторе:

- Успостављен регулаторни оквир дигитализације и дефинисане обавезе и надлежности установа културе и учесника у процесу дигитализације,

- Изграђен Национални портал за представљање дигитализованог културног наслеђа и савременог стваралаштва и

- Омогућен отворен приступ дигитализованој грађи.

Посебни циљеви у оквиру овог акционог плана су:

- Успостављен Регулаторни оквир дигитализације који уређује: обавезе и надлежности установа културе и учесника у процесу дигитализације, имплементацију међународних стандарда; интероперабилност; презентацију и промоцију дигитализоване грађе

- Омогућена компатибилност и умрежавање у областима и ситуацијама где није могуће увести јединствени информациони систем увођењем минимума заједничког именитеља дигитализоване грађе

- Развијен систем речника контролисаних термина и метаподатака за потребе описивања дигитализованог културног наслеђа и савременог стваралаштва у складу са међународним терминима и стандардима

- Отворен приступ дигитализованој грађи у јавним установама у складу са правним оквирима заштите интелектуалне својине

- Техничко-технолошка модернизација релевантних институција које се баве дигитализацијом културног наслеђа и савременог стваралаштва

- Дигитализација савременог стваралаштва, књижевности и издаваштва (е-књиге, продукција и е-трговина), музичке

www.kultura.gov.rs/lat/dokumenti/predlog-strategije-razvoja-kulture-republike-srbijeod-2017--do-2027-/-akcioni-plan-za-sprovodjenje--strategije-razvoja-kulture-republikesrbije--od-2017--do-2027--godine (прегледано 1.9.2017.) 
уметности и дискографије (интернет издања и е-трговина), укључујући остварења професионалних и аматерских друштава и удружења, дечјег стваралаштва и стваралаштва наивне и маргиналне уметности

- Образовани редовни, мастер и докторски програми на акредитованим установама високог образовања из области дигитализације

- Развијена дигитална култура и дигитална писменост

- Израђен Национални портал за активно, константно и интензивно представљање дигитализованог културног наслеђа и савременог стваралаштва

- Обједињена дигитализација културног, природног и научног наслеђа у складу са међународним стандардима и трендовима.

Мере које је неопходно акционим планом применити да би се наведени специфични циљеви остварили су:

1. Дефинисање права и обавеза учесника у процесу дигитализације кроз постојећи систем установа културе и делегирање надлежности на матичне, регионалне и локалне установе; дефинисање приоритета дигитализације културне грађе.

2. Дефинисање минималног заједничког именитеља дигитализоване грађе и специфичности имплементације и интегрисање у процес дигитализације на националном нивоу; дефинисање приоритета дигитализације; успостављање система заштите и система ограничавања приступа дигитализованој грађи; оснивање посебних организационих јединица за дигитализацију у установама културе у којима оне још не постоје.

3. Израда јединственог речника термина и метаподатака у складу са међународним стандардима.

4. Креирање регистра дигитализоване грађе, базе података и обезбеђивање најсавременијих модела интернет конекција великог протока података, приступањем постојећим академским мрежама стварањем посебног мрежног система или обезбеђивањем ових услова на други начин.

5. Осавремењивање и унапређење техничко-технолошке опремљености установа културе; јачање капацитета заопосле- 
них у установама културе за спровођење процеса дигитализације и овладавање савременим информационим и комуникационим технологијама и софтверима.

6. Увођење електонског пословања у установе културе у оквиру започетих процеса е- Управе; подстицање дигиталног стваралаштва, дигиталних и виртуелних музеја и изложби.

7. Иницирање оснивања образовних програма (основне, мастер и докторске студије) на универзитетима у Србији којим би се обезбедио потребан број кадрова за несметан развој и реализацију процеса дигитализације.

8. Израда идејног решења и израда Националног портала; израда заштитног знака (watermark) дигитализоване грађе; инсталирање Националног портала; успостављање јединственог система активног, константног и интензивног представљања дигитализоване грађе са успостављеним информационим системом надзора над поштовањем ауторских и сродних права приликом представљања дигитализованог културног наслеђа и савремног стваралаштва на Порталу.

9. Подизање свести о значају развоја дигиталне културе и дигиталне писмености; употреба информационо-комуникационе технологије у култури уз праћење трендова развоја дигиталне културе и рад на примени информационо-комуникационе технологије у култури.

10. Евидентирање постојећих културних садржаја у циљу њиховог обједињавања, али и стимулисања креативности у процесу дигитализације и оптимализације коришћења ресурса; јачање капацитета запослених за генерисање обједињене базе дигитализованог садржаја.

Дигитална агенда у Србији, сходно усклађивању политичког и регулаторног оквира за електронске комуникације са ЕУ према Министарству за телекомуникације и информационо друштво, дефинисана је Cтратегијом развоја информационог друштва до 2020. године и Стратегијом развоја е-комуникација у Србији од 2010. до 2020. године. Наведени докменти не могу се одвојено посматрати од Закона о електронским комуникацијама (донет 2010. године) и Cmpameгије развоја широкопојасног интернета у србији до 2012. године (до- 
нета 2009. године). Поред тога Србија је усвојила и Cmpameгuју за прелазак са аналогног на дигитално емитовање, Акциони план за имплементацију Агенде еSEE+ и друге прописе и акционе планове.

Стратегијом развоја информационог друштва у Републици Србији до 2020. године апострофирано је да „мотор развоја информационог друштва чине: отворен, свима доступан и квалитетан приступ Интернету; развијено е-пословање, укључујући: е-управу, е-трговину, е-правосуђе, е-здравље и е-образовање“. Отворени широкопојасни приступ обухвата приступ електронским комуникационим мрежама који омогућава велике протоке података, при чему оператор који даје услугу широкопојасног приступа оставља отворену могућност да се путем тог приступа користе независне услуге. Дигитална агенда за Србију је поставила генералне циљеве да до 2020. године буде обезбеђен широкопојасни приступ по принципу оптичког кабла до стана/зграде/кабинета до свих корисника и да буде омогућен проток од најмање $100 \mathrm{Mbps.}$

Информационо друштво у Србији након анализе акционих планова у 15 локалних самоуправа има одлике на основу којих је закључено да:

- постоје добре веб странице локалних самоуправа, али врло мало е- сервиса

- $\quad$ ни у једном акционом плану се не спомиње Информационо друштво

- у неколико акционих планова се спомиње ИКТ и интернет

- нема локалних иницијатива за повећањем широкопојасног приступа

- нема локалних иницијатива за формирањем “дигиталних градова", осим у појединим случајевима

- нема довољно обученог ИКТ кадра

- нема значајнијих иницијатива за обуку грађана за коришћење е-сервиса.

Приоритети Cтратегије за Информационо друштво Србије до 2020. дефинисани су у 6 кључних елемената:

1. Електронске комуникације

2. Е-управа, е-здравство е-правосуђе

3. ИКТ у образовању, науци и култури

4. Електронска трговина 
5. Пословни сектор ИКТ

6. Информациона безбедност.

Стратегија развоја информационог друштва у Србији до 2020 предвидела је да “До 2020. свим грађанима Републике Србије треба да буде доступан интернет високог квалитета са протоком најмање 100Mb/s" док Cтратегија развоја електронских комуникација до 2020. представља оквир за унапређење електронских комуникација, одређујући основне активности које би требало предузети како би се остварили циљеви политике развоја електронских комуникација до 2020. године. ${ }^{31}$

Заостајање Србије у широкопојасном интернет приступу може се сагледати на основу података да фиксни броудбенд (ББ) итернет приступ у Србији има 8\% корисника што је три пута мање него просек од 24.8\% у 27 земаља Европске уније (ЕУ-27), а мобилни ББ има 1.3\% корисника што је скоро пет пута мање него у ЕУ-27 (6.1\%). Осим неизграђености широкопојасне инфраструктуре, један од разлога заостајања је и економски: месечна претплата за ББ интернет приступ брзине 2 Mbps у понуди националног фиксног оператора, изражена у $€$ на паритету куповне моћи у Србији скупља је за око 50\% у поређењу са ЕУ-27 просечном понудом . Подаци о проценту појединаца који регуларно користе рачунаре показују да је Србија испод ЕУ просека, али, у детаљнијем сагледавању, изнад просека појединих земаља у региону - укључујући ЕУ чланице Румунију Бугарску и Грчку. Слична је ситуација и са појединцима који регуларно користе Интернет, Србија је испод ЕУ-27 просека али на нивоу вредности које имају Румунија, Бугарска и Грчка. ${ }^{32}$

\section{Виртуелна култура}

Подела културних добара може се одредити према покретности самих артефаката и споменика културе на непокретна култур-

31 http://www.digitalnaagenda.gov.rs/media/docs/strategija_razvoja_elektronskih_ komunikacija_u_republici_srbiji_do_2020-_godine.pdf

32 Nataša Gospić i Dragan Bogojević "Kako uhvatiti korak sa digitalnom Evropom", Izazovi Evropskih integracija, broj 2011/13, strane 67-86, ISBN: 1820-9459, Službeni Glasnik, Beograd, mart 2011. 
на добра која обухватају споменике културе, просторно културноисторијске целине, археолошка налазишта, знаменита места и покретна културна добра као што су уметничко-историјска дела, архивска грађа, аудио и филмска грађа, рукописи и стара и ретка библиотечка грађа.

Дигитализација културне баштине обухвата методе и процесе превођења аналогне форме у дигиталну, или у мањој мери креирање у изворно дигиталној форми и разликује се према типу грађе која се дигитализује (услед различитих метода и процеса скенирања, обраде, метаподатака, корпуса података за описивање):

- Дигитализација библиотечке грађе

- Дигитализација завичајне и историјске грађе

- Дигитализација архивске грађе

- Дигитализација музејске грађе.

Нови појавни облици и технолошка решења омогућавају представљање покретнихи непокретних добара културе и достигнућа савременог друштва као што су веб сајтови, апликације за мобилне телефоне и преносиве дигиталне уређаје, употреба QR кодова, увећана стварност (AR), виртуелна стварност (VR), развој интернета и концепт Интернет ствари (IoT), формирање виртуелних библиотека, музеја и виртуелних изложби уз платформе за организовање и презентацију дигитализованог садржаја у библиотекама и другим баштинским институцијама уз „облак“ технологију.

Пример виртуелне вебсајт презентације дигитализованим споменика културе у Србији је Споменици културе 33 коју је реализовао мултидисциплинарни тим Националног центра за дигитализацију са задатком формирања модела за развој електронског каталога споменика културе у Србији и дигитализације одговарајуће документације. Дигитализацијом културних ресурса и споменика од којих се неки не могу класично репрезентовати у папирним публикација, спроводи се заштита и отвара могућност специфичног проучавању споменика укључујући и библиографске референце које омогућавају даље детаљно изучавање представљених садржаја.

33 http://spomenicikulture.mi.sanu.ac.rs/ 




Апликације за мобилне телефоне и преносиве дигиталне уређаје су бројне а међу њима се истичу оне које могу представити културни садржај у дигитализованој, дигитално реалној па и виртуелној форми.

$Q R$ код као веза између физичког и дигиталног, виртуелног света (Quick Responsive Code - брз одзив, брзо декодирање и повезивање) је врста дводимензионалног бар кода, очитава се савременим преносним уређајима - читачима QR кода (мобилни, паметни телефони (smartphones), таблети и други преносни уређаји) и омогућава директан линк ка садржају који може бити број, текст, слика, вебсајт (рспективно графички, аудио, видео, мултимедијални садржај). Употреба QR кода обухвата смартфон (iPhone, Android, Blackberry) или други преносиви дигитални уређај, инсталирање апликације за скенирање QR кода, којих има велики број (Red Laser, Barcode Scanner, QR Scanner...) а највећи број ових апликација је потпуно бесплатан. Након једнократног инсталирања на уређај једноставним прелажењем камером уређаја преко QR кода аутоматски се учитава кодирани садржај. Кодирањем је успешно компримован огроман број података различитог садржаја у дводимензионални код одштампан на различтим материјалима а декодирањем се приказује текст, слика, линк ка вебсајту, односно аудио, видео запису или мултимедијалном садржају. 


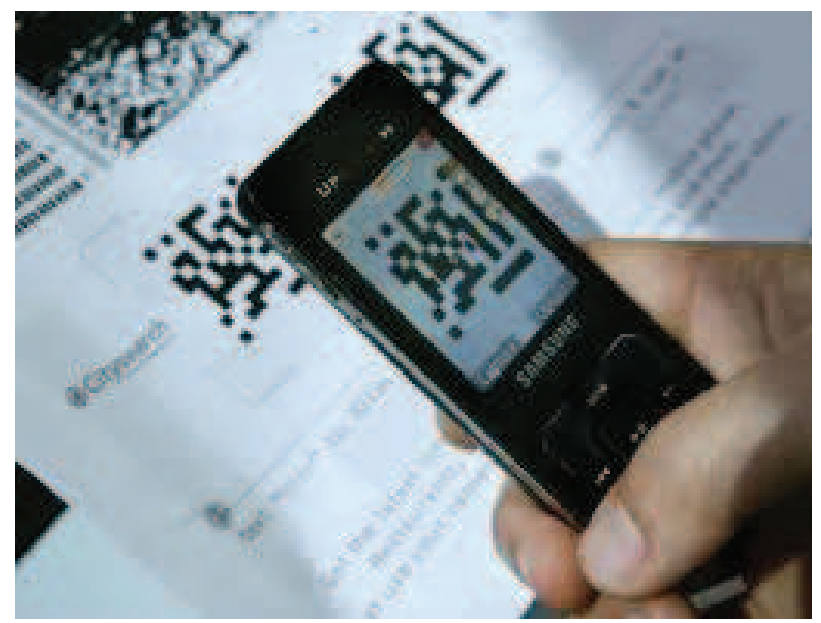

Процес коришћења AR и VR апликација је веома сличан QR принципу када је кодирањем компримован огроман број података различитог визуелног и мултимедијалног садржаја у дводимензионални код и одштампан на различтим материјалима, паноима, испод експоната у музејима, на изложбама у затвореном или на јавним местима. Након скенирања декодирањем се приступа удаљеном, виртуелном (VR) или “AR" садржају (Augmented Reality) увећане стварности, унапређене реалности.

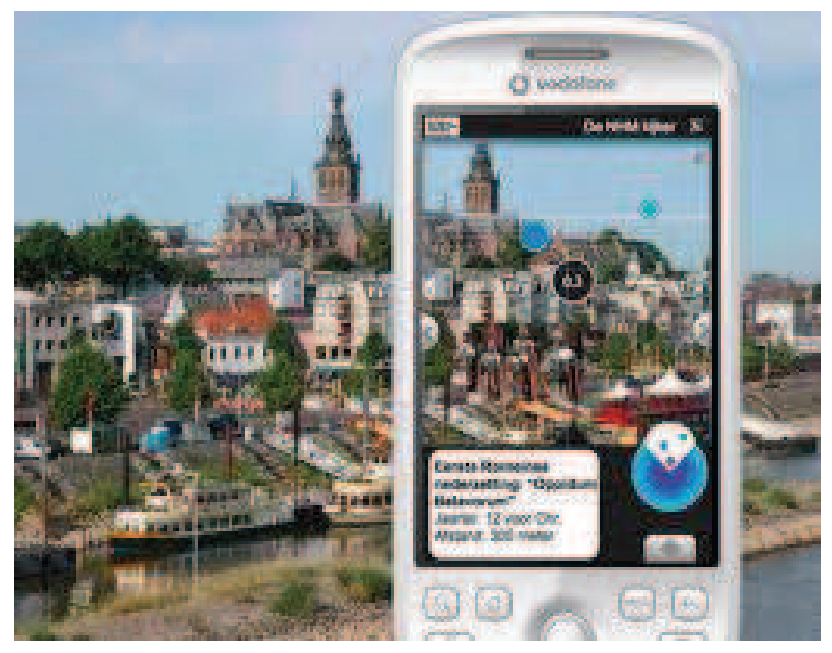


AR, VR, QR код и виртуелна културна баштина могу се довести у везу приказивањем дигиталних извора информација као и аналогних објеката историјске и културне баштине, библиотечке и музејске грађе преведених у дигитални садржај. Корисници посебних фондова библиотека, музејских збирки и други конзументи културе имају увид, информације, опис и преглед извора. Предности се огледају у једноставности и истовремености великог броја коришћења без оштећивања јединица грађе и артефаката. Виртуелно умањење и укидање временске, просторне и језичке баријере доприносе интеркултуралности док ширина и могућности примене у приказивању фондова библиотека, музеја, историјских извора на отвореним просторима, археолошких локалитета - културне баштине једног па и више народа (Римско царство и Римљани, Винча, Лепенски Вир...) омогућава презентацију очување и промоцију дигитализоване културне баштине.

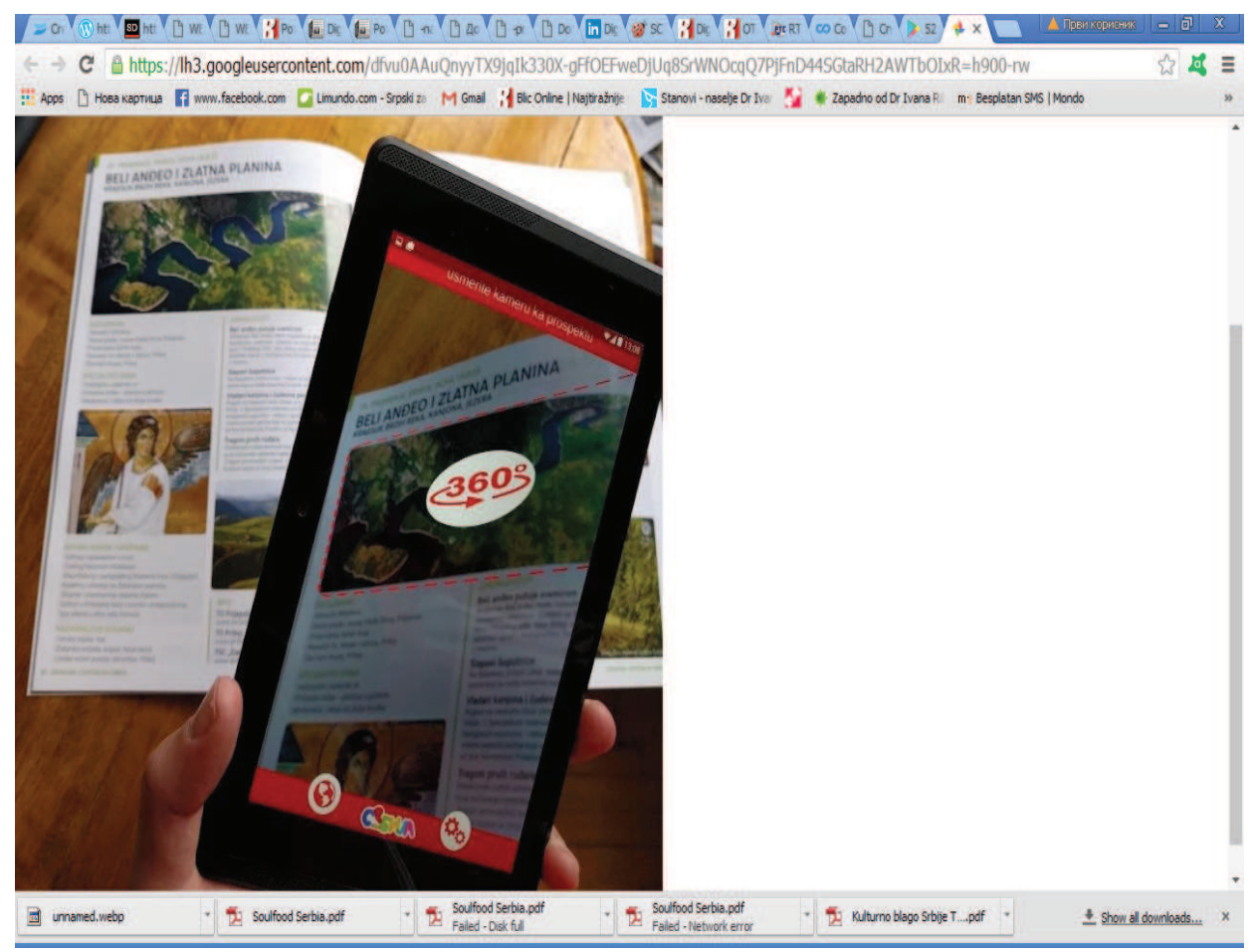


Пример апликације „52 викенда у Србији“34 за мобилне уређаје која користећи технологију увећане стварности приказује туристички потенцијал, археолошке локалитете и значајне културно-историјске споменике у Србији у 2Д, ЗД и видео садржаје

\section{Примери у библиотекама:}

- промоција аутора изложби - поред сваког рада аутора постави ce QR ко̂д који води ка веб локацији аутора или уметничког дела. На тај начин корисници могу да се информишу о самом аутору, настанку дела или његовој цени, уколико је дело на продају.

- линк ка видео или аудио тури кроз библиотеку

- употребa QR кодова за промоцију електронскихпубликација. QR кодови се постављају на картонску имитацију омота књиге која постоји само у електронском али не и у физичком облику а овај коิд води до електронског издања (имитације се смештају на полице где би по класификацији тој електронској књизи и било место).

Примери употребе виртуелне реалности у музејима:

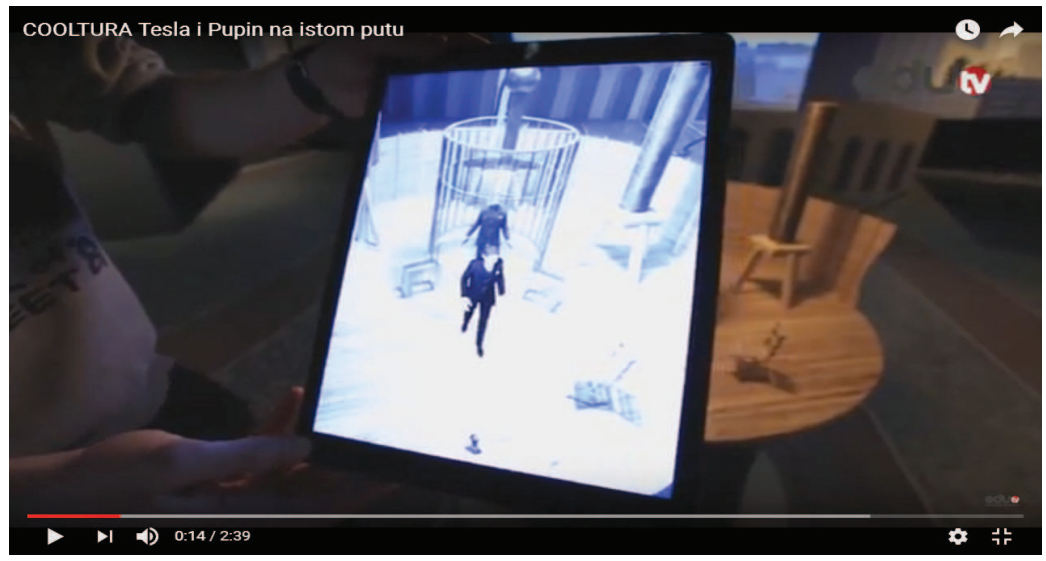

Изложба „Свет Теслиним очима”, Музеј Николе Тесле: ${ }^{35}$

$34 \mathrm{https} / / /$ play.google.com/store/apps/details?id=re.fu2.vikenda\&hl=sr

35 https://www.youtube.com/watch?v=6bCkkHzPUQY 


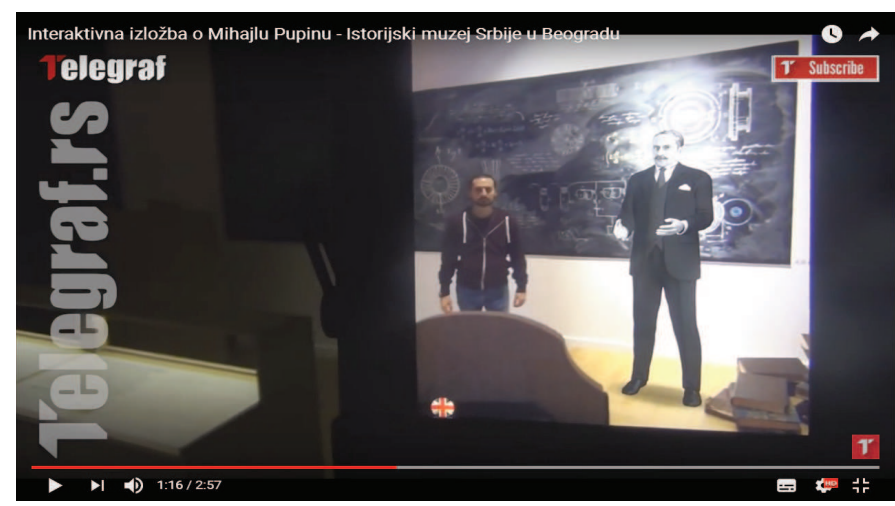

Историјски музеј Србије у Београду - Изложба о Пупину: ${ }^{36}$

Платформе за организовање и презентацију дигитализованог садржаја у библиотекама и другим баштинским институцијама уз „облак“ технологију (LoCloud, Omeka...) омогућују формирање виртуелних библиотека, музеја и виртуелних изложби при чему се дигитализовани садржај библиотеке, музеја или друге баштинске институције може смештати и чувати (хостовати) на серверима ван матичне институције, у „облаку“, често бесплатно, и организовати у колекције и приказивати кроз виртуелне изложбе:

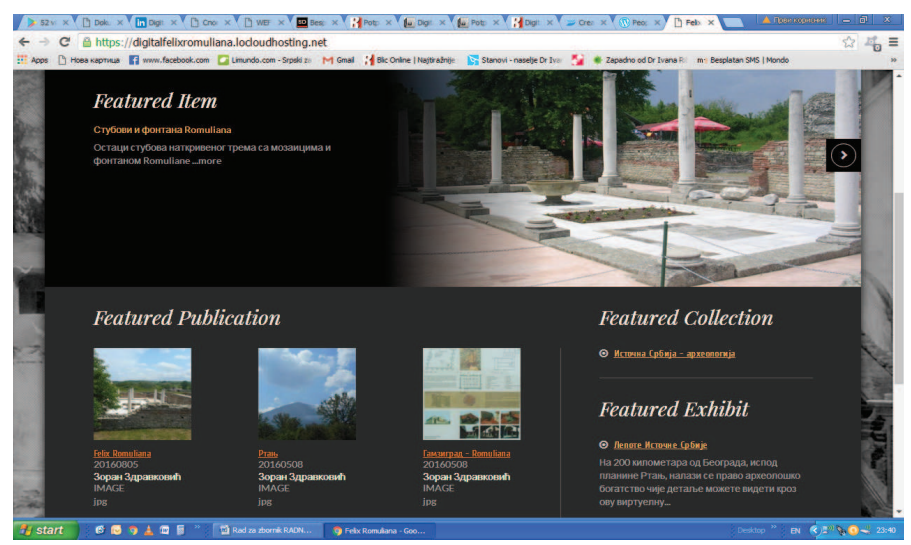

Приказ виртуелне изложбе дигиталне презентације Digital Felix Romuliana на LoCloud платформи ${ }^{37}$

36 https://www.youtube.com/watch?v=MmuhNy-wGDA

37 https://digitalfelixromuliana.locloudhosting.net/ 


\section{Литература}

Katz, Raúl L. and Koutroumpis, Pantelis, „Measuring digitization: A growth and welfare multiplier", Technovation, Volume 33, Issues 10-11, October-November 2013, pp 314-319, (2013), http://www.teleadvs.com/wp-content/uploads/Technovation RK_PK.pdf (преузето 17.3.2017), DOI:10.1016/j.technovation.2013.06.004 ; (MEASURING the Information Society Report 2014, Geneva, International Telecommunication Union, стр. 35-37, URL (1.3.2017): https://www.itu.int/en/ ITU-D/Statistics/Documents/publications/mis2014/MIS2014_without_Annex_4.pdf

MISR извештај: MEASURING the Information Society Report 2014, Geneva, International Telecommunication Union, cTp. 35, URL (17.3.2017): https://www.itu.int/en/ITU-D/ Statistics/Documents/publications/mis2014/MIS2014_without_Annex_4.pdf

Measuring the Information Society Report 2015, International Telecommunication Union, Place des Nations, Geneva, Switzerland, URL (12.3.2017): https://www. itu.int/dms_pub/itu-d/opb/ind/D-IND-ICTOI-2015-SUM-PDF-E.pdf

Katz, Raúl L., Using a Digitization Index to measure the Economic and Social Impact of Digital Agendas, стр. 7, http://www.eurocpr.org/data/2013/Katz.pdf (преузето 1.3.2017)

Rade Stankić, Marko Stankić, „Merenje ekonomskog i društvenog uticaja informacionokomunikacionih tehnologija", Нови економист, бр. 14

Europe 2020 strategy, European Commision, Brussels, 2010, http://ec.europa.eu/ europe2020/index_en.htm (преузето 12.3.2017)

Europe 2020, http://ec.europa.eu/europe2020/index_en.htm (преузето 1.3.2017)

Europe 2020 strategy, European Commision, Brussels, 2010, http://ec.europa.eu/ europe2020/index_en.htm (преузето 1.3.2017)

Bogojević Dragan, Gospić Nataša, „Digitalna agenda: Evropa i Srbija”, (rad predstavljen na XXVIII Simpozijum o novim tehnologijama u poštanskom i telekomunikacionom saobraćaju - PosTel 2010, Beograd, Srbija, 14-15. decembar 2010.

Cmpameгuја развоја културе Републике Србије од 2017. до 2027, нацрт, Министарство културе Републике Србије, мај 2017, URL: http://www.kultura. gov.rs/docs/dokumenti/nacrt-strategije-razvoja-kulture-republike-srbije-od2017--do-2027-/-nacrt-strategije-razvoja-kulture-republike-srbije-od-2017-do-2027-.pdf прегледано 1.9.2017

Акциони план за спровођење Стратегије развоја културе Републике Србије од 2017. до 2027. године, Министарство културе Републике Србије, 2017, стр. 70, URL: http://www.kultura.gov.rs/lat/dokumenti/predlog-strategije-razvojakulture-republike-srbije-od-2017--do-2027-/-akcioni-plan-za-sprovodjenje-strategije-razvoja-kulture-republike-srbije--od-2017--do-2027--godine (прегледано 1.9.2017.) 


\section{Zoran Zdravković}

\section{VIRTUAL CULTURE IN THE DEVELOPMENT, PRESENTATION AND PRESERVATION OF THE CULTURE OF MODERN SOCIETY}

\section{Summary}

The development of society and modern technology have led to the formation of new forms of manifestations of society such as information society and digital society and the emergence of virtual organizations and virtual communities. The paper will present the importance of ICT in modern society, the digital environment and digitalization processes first through the plans, strategies and the Digital Agenda (in Europe and in Serbia), then the present state of society and the most important results of their application. Virtual culture will be considered through new forms that allow the presentation of the culture and achievements of modern society: QR codes, augmented reality (AR), virtual reality (VR), Internet development and Internet of Things concept (IoT), followed by the formation of virtual libraries, with the Cloud technology and examples of LoCloud platform for the organization and presentation of digitized content in libraries and other cultural heritage institutions, the promotion of digital literacy in society and preservation of culture.

Key Words: Virtual Culture, Information-communication Technology, Digitization, Digital literacy 